\title{
Efektivitas dan Keberlanjutan Program Pengembangan Sarana Prasarana Pertanian di Kabupaten Lamongan
}

\section{Effectiveness and Sustainability of Agricultural Infrastructure Development Program in Lamongan Regency}

${ }^{\square}$ Lailatul Fitriyah

Magister Perencanaan Wilayah dan Kota, Universitas Gadjah Mada Yogyakarta, Jawa Tengah, Indonesia

DOI: $10.32781 /$ cakrawala.v15i1.373

\begin{tabular}{l}
\hline ARTICLE INFO \\
Efektivitas, \\
Keberlanjutan, \\
Sarana Prasarana Pertanian, \\
Lamongan.
\end{tabular}

Article History:

Received : 26 April 2021

Accepted : 16 Juni 2021

Publish : 17 Juni 2021

\begin{abstract}
Abstrak:
Kabupaten Lamongan merupakan daerah penghasil padi terbesar di Jawa Timur dengan 839.742ton pada tahun 2020.Sebagai penghasil padi terbesar maka diperlukan program dan kegiatan yang mendukung kebijakan peningkatan produksipadi.Salahsatunya adalah pelaksanaan program pengembangan sarana prasarana pertanian yang mempunyai empat kegiatan yaitu pengembangan sumber - sumber air untuk irigasi air permukaan, pembangunan jalan usaha tani, pembangunan dan atau rehabilitasi jaringan irigasi Jitut dan Jides serta pengadaan sarana prasarana teknologi tepat guna.Program pengembangan sarana prasarana pertanian juga digunakan untuk mengatasi permasalahan dalam pencapaian peningkatan produksi padi yaitu banjir dan kekeringan yang rutin melanda Kabupaten Lamongan.Tujuan dari penelitian ini adalah mengetahui efektivitas dan keberlanjutan dari program pengembangan sarana prasarana pertanian.Metode yang digunakan adalah deskriptif kualitatif dengan alur pemikiran deduktif.Hasil yang diperoleh dari penelitian ini adalah program pengembangan sarana prasarana pertanian efektif dalam mencapai hasil yang diinginkan namun tidak mengalami keberlanjutan.
\end{abstract}

\section{Abstract:}

Lamongan Regency is the largest rice-producing area in East Java with 839,742 tons in 2020. As the largest rice producer, programs and activities are needed that support the policy of increasing rice production. One of them is the agricultural infrastructure development program which has four activities, namely the development of water sources for surface water irrigation, the construction of farm roads, construction and/or rehabilitation of the Jitut and Jides irrigation networks and the provision of appropriate technology infrastructure. Agricultural infrastructure development programs are also used to overcome problems in achieving increased rice production, namely floods and droughts that routinely hit Lamongan Regency. The purpose of this study is to determine the effectiveness and sustainability of agricultural infrastructure development programs. The method used was descriptive qualitative with a deductive line of thought. The results obtained from this research are that the agricultural infrastructure development program is effective in achieving the desired results but does not experience sustainability.

\footnotetext{
${ }^{\triangle}$ Corresponding author:

Address : Bulaksumur, Caturtunggal, Kec. Depok,

Kab Sleman, Daerah Istimewa Yogyakarta 55281 


\section{PENDAHULUAN}

Dalam rencana tata ruang wilayah Provinsi Jawa Timur tahun 2011 - 2031, Kabupaten Lamongan masuk dalam Pusat Kegiatan Nasional (PKN) Gerbangkertasusila dan Malang serta Kawasan Strategis Nasional (KSN) Gerbangkertasusila dengan sudut kepentingan ekonomi serta masuk dalam wilayah pengembangan Germakertasusila Plus. Selain itu dalam RPJMD Provinsi Jawa Timur tahun 2019 - 2024 Kabupaten Lamongan masuk dalam Kabupaten dengan prioritas penanganan wilayah untuk peningkatan cakupan infrastruktur dasar, peningkatan sektor unggulan serta untuk pengurangan kemiskinan serta masuk dalam klaster pengembangan Labanegoro (Lamongan, Tuban dan Bojonegoro), ketiga kabupaten ini memiliki tingkat kemiskinan yang tinggi dari pada Provinsi serta tingkat pengangguran tinggi walaupun industri sudah masuk diketiga kabupaten tersebut.

Tujuan pembangunan wilayah adalah untuk meningkatkan kesejahteraan masyarakat. Guna mengetahui tingkat kesejahteraan masyarakat, maka perlu diketahui nilai dari Indeks pembangunan manusia serta tingkat kemiskinan. Indeks pembangunan manusia di Kab. Lamongan mengalami peningkatan meskipun sedang yaitu dari 71,97 menjadi 72,57 dan menjadi urutan ke-16 di Provinsi Jawa Timur (BPS Kabupaten Lamongan, 2020). Sedangkan untuk garis kemiskinan pada tahun 2019, Kabupaten Lamongan mengalami peningkatan sebesar $7,34 \%$ namun masih di bawah garis kemiskinan Provinsi sedangkan untuk jumlah penduduk miskin hanya mengalami penurunan sebesar $0,59 \%$ dari tahun sebelumnya. Bahkan Kabupaten Lamongan belum pernah mengalami penurunan jumlah penduduk miskin lebih dari $1 \%$ (BPS Kabupaten Lamongan, 2020).

Sektor Pertanian, kehutanan dan perikanan di Kabupaten Lamongan menjadi sektor utama dalam PDRB dari tahun 2016
- 2019 dengan nilai 8,2 hingga 8,5 triliun rupiah, dengan rata - rata pertumbuhan sebesar 1\%. (BPS Kabupaten Lamongan, 2019).Hal ini berarti sektor pertanian, perikanan serta kehutanan dapat dijadikan sektor unggulan untuk pengembangan ekonomi wilayah guna melaksanakan pembangunan daerah.Namun demikian, tidak diimbangi dengan banyaknya jumlah tenaga kerja di sektor pertanian, kehutanan dan perikanan. Data analisis jumlah penduduk pada tahun 2017, hanya $39 \%$ dari jumlah total penduduk usia kerja (15 tahun ke atas) yang bekerja di sektor pertanian, kehutanan dan perikanan dan terus mengalami penurunan menjadi $32 \%$ di tahun 2019. Sehingga diperlukan teknologi untuk mengimbangi jumlah tenaga kerja.

Namun untuk jumlah produksi padi yang terus mengalami peningkatan. Bahkan sejak tahun 2017 Kabupaten Lamongan menjadi penghasil padi terbanyak dari seluruh kabupaten dan kota di Provinsi Jawa Timur. Selain itu dari faktor produktivitas padi tahun 2019 di Kabupaten Lamongan juga masih diatas rata - rata produktivitas padi nasional sebesar 7,53 ton/ha (BPS Kabupaten Lamongan, 2020). Menurut Istighfaroh (2016) produksi padi di Kabupaten Lamongan dipengaruhi oleh adanya jaringan irigasi, penggunaan pupuk serta luas panen. Hal ini juga didukung oleh luasnya lahan pertanian di Kabupaten Lamongan. Data BPS Kabupaten Lamongan tahun 2019 menyebutkan bahwa luas lahan pertanian sawah seluas 87.990,25 Ha sedangkan luas lahan pertanian bukan sawah seluas $61.814 \mathrm{Ha}$.

Dalam mengoptimalkan pemanfaatan lahan pertanian, banyak tantangan yang harus dihadapi. Salah satu tantangan besar yang harus dihadapi adalah masalah ketersediaan air, yaitu banjir dan kekeringan. Menurut data Dinas Tanaman Pangan, Hortikultura dan Perkebunan, banjir dan kekeringan yang paling parah terjadi pada tahun 2017 dengan luas lahan 
pertanian yang terkena banjir seluas 536 Ha dengan taksiran kerugian sebesar 5,6 milyar rupiah, sedangkan luas lahan pertanian yang mengalami kekeringan seluas 20.184 Ha dengan taksiran kerugian sebesar 29 miliar rupiah. Selain banjir, tantangan yang harus dihadapi adalah kekeringan. Faktor penyebab utama kekeringan di Kabupaten Lamongan adalah ketersediaan air, banyaknya jaringan irigasi yang mengalami kerusakan dan beralih fungsi menjadi drainase serta kurangnya penampungan air untuk menampung aliran air permukaan pada musim penghujan. Sebanyak 50.000 ha lahan pertanian Kabupaten Lamongan masih banyak yang terancam kekeringan (Wibisana, 2017). Kurangnya penampungan air menyebabkan penambahan lahan kritis di Kabupaten Lamongan. Luas lahan kritis pada tahun 2019 mengalami penambahan dari tahun 2018 seluas $1.440 \mathrm{Ha}$ menjadi $3.957 \mathrm{Ha}$ (Dinas Tanaman Pangan, Hortikultura dan Perkebunan, 2019).

Kebijakan untuk mengatasi permasalahan tersebut Pemerintah Kabupaten Lamongan dalam Rencana Pembangunan Jangka Menengah Daerah (RPJMD) Kabupaten Lamongan tahun 2016-2021 melaksanakan program pengembangan sarana prasarana pertanian.Kegiatan utama program pengembangan sarana prasarana pertanian adalah pembangunan prasarana fisik seperti embung, dam parit, long storage, sumur panthek, jaringan irigasi dan jalan usaha tani serta pemberian bantuan berupa alat mesin pertanian. Berdasarkan indikator kinerja utama yang tertuang dalam Rencana Strategis Dinas Tanaman Pangan, Hortikultura dan Perkebunan tahun 2016-2021, program pengembangan sarana prasarana pertanian mempunyai tujuan untuk peningkatan produksi pertanian serta peningkatan pendapatan petani. Pada tahun 2015-2017 atau sebelum pelaksanaan program pengembangan sarana prasarana pertanian terjadi peningkatan jumlah produksi padi namun setelah pelaksanaan program pengembangan sarana prasarana pertanian terjadi penurunan produksi padi sebesar 5\%. Pernah dilakukan penelitian tentang dampak sarana prasarana pertanian terutama jaringan irigasi yang menghasilkan bahwa jaringan irigasi mampu meningkatkan produktivitas hasil pertanian sehingga menyebabkan pendapatan petani mengalami kenaikan dan terjadi peningkatan daya beli masyarakat (Rahmaniar, 2018).

Program pengembangan sarana prasarana pertanian juga mendukung visi dan misi kedua RPJMD Kabupaten Lamongan. Sasaran pada misi kedua RPJMD Kabupaten Lamongan yaitu untuk meningkatkan pertumbuhan lapangan usaha pertanian dan kesejahteraan petani dengan indikatornya adalah nilai tukar petani (NTP) serta pertumbuhan PDRB sektor pertanian. Jika dilihat pada tahun sebelum pelaksanaan program pengembangan sarana prasarana pertanian yaitu tahun 2015-2017, nilai tukar petani (NTP) berkisar antara 102 hingga 104,66 masih berada di bawah Provinsi Jawa Timur. Sedangkan PDRB sektor pertanian mengalami peningkatan meski hanya sebesar $1 \%$.

Pernah dilakukan penelitian tentang sarana prasarana pertanian yang sudah seperti penelitian yang bertujuan untuk mengevaluasi kinerja dari embung Oeltua di Desa Oeltua Kecamatan Tebenu Kabupaten Kupang dengan memberikan penilaian terhadap sikap, pendapat dan persepsi masyarakat tentang kejadian dan gejala sosial (Dethan dkk, 2015). Penelitian lainnya tentang dampak pembangunan jalan usaha tani yang berada di Kabupaten Sleman. Penelitian dilakukan dengan metode overlay menggunakan Sistem Informasi Geografis (SIG), dari overlay didapatkan bahwa terjadi perubahan alih fungsilahan pertanian setelah dibangunjalan usaha tani (Suminar, 2018). Dari sejumlah permasalahan tersebut dilakukanpenelitian 
evaluasi yang bertujuan untuk mengetahui efektivitas dan keberlanjutan program pengembangan sarana prasarana pertanian terutama keterkaitannya dalam mendukung tujuan pembangunan di Kabupaten Lamongan.

\section{TINJAUAN PUSTAKA}

Sejak awal kemerdekaan Indonesia, tujuan utama pembangunan adalah untuk mengejar pertumbuhan ekonomi (Saragih, 2017). Sehingga hal ini memicu pemerintah untuk membuat kebijakankebijakan yang harus dilaksanakan oleh instansi-instansi di daerah. Pembangunan seperti ini justru mengalami kelemahan yaitu masyarakat yang berada di daerah tidak dilibatkan secara langsung dalam proses pembangunan baik pengambilan keputusan, perencanaan dan pelaksanaan kebijakan. Namun sejak dikeluarkannya undang-undang No. 22 tahun 1999 tentang pemerintah daerah maka secara tertulis pemerintah pusat memberikan kewenangan kepada pemerintah daerah untuk mengatur pembangunan di wilayahnya sendiri atau disebut dengan otonomi daerah. Selanjutnya UU ini kemudian diperbaharui oleh UU NO.32 Tahun 2004 dan diperbaharui lagi oleh UU N0.23 tahun 2014 tentang pemerintah daerah. Konsep otonomi daerah yang bertanggungjawab adalah mengatur dan mengurus rumahtangga sendiri berdasarkan aspirasi masyarakat dan potensi sumber daya yang dimiliki (Saragih, 2017). Perencanaan pembangunan suatu wilayah menurut Tarigan (2007), perencanaan pembangunan wilayah dibagi menjadi dua yaitu perencanaan penggunaan wilayah yang diatur dalam rencana tata ruang wilayah $(\mathrm{RT} / \mathrm{RW})$ dan perencanaan kegiatan dalam ruang wilayah tersebut yang diatur dalam rencana pembangunan daerah. Selain itu Dusseldorp dan Staveren dalam Saragih (2017) menyatakan bahwa perencanaan wilayah bersifat integratifyang berarti berhubungan dengan perencanaan yang lain, misalnya perencanaan nasional, sektoral dan perencanaan desa. Selain itu perencanaan wilayah juga bersifat komprehensif yang berarti mencangkup berbagai aspek seperti aspek sosial, ekonomi, fisik dan aspek teknis dari suatu perencanaan.

Miraza (2005), menyatakan perencanaan pembangunan wilayah bertujuan untuk kesejahteraan masyarakat yang memerlukan unsur sumber daya manusia, sumber daya alam, infastruktur, teknologi dan budaya. Salah satu cara untuk mencapai kesejahteraan masyarakat adalah dengan melaksanakan strategi pengembangan ekonomi lokal (PEL). Bartik dalam Saragih (2017) mendefinisikan pengembangan ekonomilokal sebagaipeningkatan ekonomi daerah dengan memanfaatkan tenaga kerja serta lahan secara produktif sehingga dapat meningkatkan pendapatan masyarakat. Selain itu pengembangan ekonomi wilayah menurut ILO juga diartikan sebagai proses partisipatif pembangunan wilayah administratif yang dilakukan oleh pemangku kepentingan publik dan swasta dengan menggunakan sumber daya lokal dan keunggulan kompetitif untuk menciptakan kesempatan kerja serta pertumbuhan ekonomi secara berkelanjutan (Saragih, 2017). Pengembangan ekonomi lokal menjadi alternatif kebijakan topdown yang menyebabkan disparitas wilayah akibat eksploitasi sumber daya alam serta kebijakan bottomup yang lemah dalam hal implementasi.

Ketersediaan Sumber daya Alam (SDA) menjadi modal pokok dalam pengembangan ekonomi wilayah.Namun SDA bukan satu-satunya faktor penentu keberhasilan perkembangan ekonomi wilayah. Misalnya terdapat suatu daerah dengan SDA yang melimpah namun memiliki PDRB yang rendah, hal ini bisa jadi diakibatkan oleh faktor teknologi, baik teknologi yang melekat pada sumber daya manusia yaitu keterampilan, wirausaha 
dan manajerial maupun teknologi yang berupa infrastruktur. Peran teknologi dalam ekonomi wilayah telah dimodelkan oleh teori Douglas (Pramono dan Suminar, 2019).

Untuk mengetahui keberhasilan program, maka dilakukan evaluasi pada program tersebut. Evaluasi menurut Winarno (2014) adalah proses penilaian kebijakan tidak hanya pada setelah pelaksanaan kebijakan namun pada seluruh tahapan atau proses kebijakan. Sedangkan menurut Organization for Economic Cooperation and Development (OECD), evaluasi adalah proses pemberian nilai suatu kegiatan, program atau kebijakan secara sistematis dan objektif terhadap sebuah intervensi yang direncanakan, sedang berlangsung dan sudah selesai. Dalam evaluasi diperlukan kriteria-kriteria untuk mempermudah dalam mengevaluasi kebijakan atau program.Kriteria yang digunakan dalam penelitian ini adalah efektivitas dan keberlanjutan. Efektivitas adalah seberapa jauh ketercapaian dari tujuan atau hasil yang diinginkan (Dunn, 2003). Efektivitas juga diartikan hasil yang ingin dicapai telah sesuai dengan target dan manfaat yang diharapkan dan apa saja tindak lanjut dari pencapaian tersebut (Bappenas RI, 2017). Sedangkan Keberlanjutan adalah untuk mengetahui keberlanjutan dari program jika sudah tidak ada intervensi dari pemerintah (Bappenas RI, 2017).

\section{METODE PENELITIAN}

Penelitian dilaksanakan di seluruh wilayah Kabupaten Lamongan, terutama pada wilayah kelompok tani yangmendapat bantuan dari program pengembangan sarana prasarana pertanian.Penelitian ini termasuk dalam penelitian evaluasi yang bersifat deskriptif serta menggunakan pendekatan kualitatif. Peneliti melakukan eksplorasi secara mendalam terhadap program, kejadian proses serta aktivitas masyarakat dalam pelaksanaan program (Cresswell, 2017). Selain itu penelitian evaluasi juga menggunakan alur pemikiran deduktif sehingga diperlukan variabelvariabel untuk melihat dan menguji kenyataannya di lapangan. Variabel pada penelitian didapatkan dari kerangka kerja logis program pengembangan sarana prasarana pertanian. Berikut ini variabel penelitian yang digunakan pada tabel 1 .

Tabel 1 Variabel dalam penelitian

\begin{tabular}{|c|c|c|}
\hline Kriteria & Variabel & Indikator \\
\hline \multirow[t]{4}{*}{ Efektivitas } & \multirow{4}{*}{$\begin{array}{l}\text { Standart } \\
\text { output }\end{array}$} & Jumlah sumber - sumber air yang memiliki volume $\geq 500 \mathrm{~m}^{3}$ \\
\hline & & Jumlah jalan usaha tani yang memiliki lebar $\geq 2 \mathrm{~m}$ \\
\hline & & $\begin{array}{l}\text { Jumlah jaringan irigasi (Jitut dan Jides) yang memiliki debit } \geq \\
5 \text { liter/detik }\end{array}$ \\
\hline & & $\begin{array}{l}\text { Jumlah sarana prasarana pertanian yang tersalurkan sebanyak } \\
2 \%\end{array}$ \\
\hline \multirow[t]{5}{*}{ Keberlanjutan } & \multirow{4}{*}{$\begin{array}{l}\text { Kualitas } \\
\text { output }\end{array}$} & Jumlah sumber - sumber air yang memiliki volume $\geq 500 \mathrm{~m}^{3}$ \\
\hline & & Jumlah jalan usaha tani yang memiliki lebar $\geq 2 \mathrm{~m}$ \\
\hline & & $\begin{array}{l}\text { Jumlah jaringan irigasi (Jitut dan Jides) yang memiliki debit } \geq \\
5 \text { liter/detik }\end{array}$ \\
\hline & & Jumlah sarana prasarana pertanian dalam bentuk UPJA \\
\hline & $\begin{array}{l}\text { Peran serta } \\
\text { masyarakat }\end{array}$ & $\begin{array}{l}\text { Jumlah kegiatan yang melibatkan masyarakat dalam } \\
\text { pengelolaan dan penelitian }\end{array}$ \\
\hline
\end{tabular}

Sumber: Data Sekunder, 2020 
Penelitian ini menggunakan data primeryang diperoleh dengan observasi langsung, pengukuran unit pengamatan secara langsung serta wawancara kepada narasumber.Narasumber berupa kelompok tani penerima bantuan atau pelaksana kegiatan.Unit amatan yang dijadikan objek pengamatan adalah empat kegiatan pada progam pengembangan sarana prasarana pertanian yaitu kegiatan pengembangan sumber - sumber air untuk irigasi air permukaan yang berupa bangunan embung, dam parit,long storage dan sumur panthek, kegiatan pembangunan jalan usaha tani, kegiatan pembangunan dan atau rehabilitasi jaringan irigasi tingkat usaha tani (Jitut) dan jaringan irigasi desa (Jides) serta kegiatan pengadaan sarana prasarana teknologi tepat guna (alat mesin pertanian). Jumlah unit amatan atau populasi pada penelitian ini seperti pada tabel 2. Pengambilan data efektivitas didapatkan dari dokumen perencanaan kegiatan pada program pengembangan sarana prasarana pertanian yang berupa volume sumber - sumber air permukaan, lebar jalan usaha tani, debit aliran pada jaringan irigasi serta jumlah alat mesin pertanian yang disalurkan dan dilakukan observasi atau pengukuran langsung di lapangan sebagai kondisi awal unit amatan yang berupa kegiatan - kegiatan pada program pengembangan sarana prasarana pertanian dengan diperkuat dengan hasil wawancara. Sedangkan data yang digunakan pada kriteria keberlanjutan adalah sama dengan data efektivitas namun data diambil pada kondisi saat ini yang didapatkan dengan pengukuran langsung di lapangan sebagai kondisi akhir atau kondisi saat dilakukan penelitian yang diperkuat dengan hasil wawancara narasumber. Narasumber wawancara adalah ketua atau anggota kelompok tani yang mengetahui proses atau pelaksanaan dari kegiatankegiatan pada program pengembangan sarana prasarana pertanian.

\section{Analisis Data}

Analisis data dilakukan dengan mengkategorikan sub-kegiatan atau kegiatan pada indikator-indikator yang sudah ditetapkan. Jika indikator terpenuhi maka sub kegiatan atau kegiatan tersebut disimpulkan berhasil. Selanjutnya jika jumlah sub kegiatan atau kegiatan yang berhasil $\geq 50 \%$ maka kegiatan dan program tersebut disimpulkan efektif dan keberlanjutan. Kecuali pada kegiatan pengadaan sarana prasarana teknologi

Tabel 2 Jumlah Unit Amatan atau Populasi pada Penelitian

\begin{tabular}{lll}
\hline Kegiatan & Subkegiatan & Jumlah \\
\hline Pengembangan sumber - sumber air untuk & Pembangunan embung & 16 \\
\cline { 2 - 3 } irigasi air permukaan & Pembangunan dam parit & 15 \\
\cline { 2 - 3 } & Pembangunan long storage & 48 \\
\cline { 2 - 3 } & Pembangunan sumur panthek & 5 \\
\hline Pembangunan jalan usaha tani & - & 28 \\
\hline $\begin{array}{l}\text { Pembangunan dan atau rehabilitasi Jitut dan } \\
\text { Jides }\end{array}$ & - & 30 \\
\hline Pengadaan sarana prasarana teknologi tepat & & Traktor roda empat \\
\cline { 2 - 3 } guna & Hand traktor & 3 \\
\cline { 2 - 3 } & Power thresher & 26 \\
\cline { 2 - 3 } & Pompa air 4 dim & 3 \\
\cline { 2 - 3 } & Pompa air 6 dim & 26 \\
\cline { 2 - 3 } & Transplanter & 30 \\
\hline
\end{tabular}

Sumber: Data Sekunder, 2020 
tepat guna, efektivitas dan keberlanjutan akegiatan langsung disimpulkan jika indikator variabel terpenuhi.

\section{HASIL DAN PEMBAHASAN \\ Efektivitas Program Pengembangan Sarana Prasarana Pertanian}

Menurut Bappenas (2017), efektivitas adalah penggambaran dari hasil yang ingin dicapai, apakah sudah sesuai dengan yang diinginkan atau ditargetkan. Pada program pengembangan sarana prasarana pertanian terdapat empat kegiatan yang masingmasing mempunyai hasil yang diinginkan berbeda beda. Pada kegiatan pengembangan sumber-sumber air untuk irigasi air permukaan hasil yang diinginkan adalah adanya ketersediaan air pada penampungan air permukaan yang digunakan untuk irigasi pertanian.Sedangkan pada kegiatan pembangunan jalan usaha tani hasil yang diinginkan adalah adanya kelancaran mobilitas transportasi.Pada kegiatan pembangunan dan atau rehabilitasi jaringan irigasi Jitut dan Jides hasil yang dinginkan yaitu adanya kelancaran air pada saluran irigasi serta pada kegiatan pengadaan sarana prasarana teknologi pertanian hasil yang diinginkan adalah peningkatan pendapatan petani dengan pengelolaan dalambentuk unit pelayanan jasa alat mesin pertanian (UPJA). Dari hasil pengumpulan data di lapangan pada unit amatan seperti tabel 2 serta analisis data maka didapatkan hasil efektivitas program pengembangan sarana prasarana pertanian pada tabel 3 .

Pada tabel 3, kegiatan pengembangan sumber-sumber air untuk irigasi air permukaan terdapat dua sub kegiatan yang tidak berhasil yaitu pembangunan dam parit serta sumur panthek. Penyebab ketidakberhasilan adalah lokasi pembangunan dam parit yang berlokasi di wilayah sawah tambak sehingga pemanfaatannya tidak untuk pemenuhan kebutuhan pengairan untuk pertanian namun lebih dimanfaatkan untuk kemudahan dalam pengaturan air pada perikanan serta untuk transportasi sungai.

Tabel 3 Hasil Penelitian Efektivitas Program Pengembangan Sarana Prasarana Pertanian

\begin{tabular}{|c|c|c|c|}
\hline \multirow[t]{2}{*}{ Kegiatan } & \multirow[t]{2}{*}{ Sub kegiatan } & \multicolumn{2}{|c|}{ Efektivitas } \\
\hline & & $\begin{array}{c}\text { Standar } \\
\text { output }\end{array}$ & Kesimpulan \\
\hline \multirow{4}{*}{$\begin{array}{l}\text { Pengembangan sumber - sumber air } \\
\text { untuk irigasi air permukaan }\end{array}$} & Pembangunan embung & $81,3 \%$ & Berhasil \\
\hline & Pembangunan dam parit & $33 \%$ & Tidak berhasil \\
\hline & $\begin{array}{l}\text { Pembangunan long stor- } \\
\text { age }\end{array}$ & $96 \%$ & Berhasil \\
\hline & $\begin{array}{l}\text { Pembangunan sumur } \\
\text { panthek }\end{array}$ & $0 \%$ & Tidak berhasil \\
\hline Pembangunan jalan usaha tani & - & $78 \%$ & Berhasil \\
\hline $\begin{array}{l}\text { Pembangunan dan atau rehabilitasi } \\
\text { Jitut dan Jides }\end{array}$ & - & $74 \%$ & Berhasil \\
\hline \multirow{6}{*}{$\begin{array}{l}\text { Pengadaan sarana prasarana teknolo- } \\
\text { gi tepat guna }\end{array}$} & Traktor roda empat & $0 \%$ & Tidak berhasil \\
\hline & Hand traktor & $22 \%$ & Berhasil \\
\hline & Power thresher & $50 \%$ & Berhasil \\
\hline & Pompa air 4 dim & $75 \%$ & Berhasil \\
\hline & Pompa air 6 dim & $0 \%$ & Tidak berhasil \\
\hline & Transplanter & $0 \%$ & Tidak berhasil \\
\hline
\end{tabular}

Sumber: Data Primer Diolah, 2020 
Sedangkan pada sumur panthek meskipun dibangun pada lokasi sawah tadah hujan namun lokasi pembangunan sumur panthek adalah lokasi yang petani sebagian besar sudah memiliki sumur panthek pribadi sehingga sumur panthek dari kegiatan hanya sedikit yang memanfaatkan. Pada sub kegiatan embung meskipun $83 \%$ embung sudah efektif dalam ketersediaan air namun ada sebagian embung yang dimanfaatkan untuk rumah tangga.

Sedangkan pada kegiatan pembangunan jalan usaha tani, terdapat $22 \%$ jalan usaha tani yang terbangun pada lahan sawah tambak dengan lebar hanya $1 \mathrm{~m}$. Dengan lebar $1 \mathrm{~m}$, jalan usaha tani tidak dapat dilewati oleh kendaraan roda tiga (sesuai dengan teknis kegiatan pembangunan jalan usaha tani Kementerian Pertanian) sehingga mobilitas transportasi tidak mengalami kelancaran dan hasil tidak tercapai. Namun demikian jumlah jalan usaha tani yang mempunyai lebar $2 \mathrm{~m}$ sudah lebih dari 50\% sehingga dapat disimpulkan bahwa kegiatan pembangunan jalan usaha tani efektif. Pada kegiatan pembangunan dan atau rehabilitasi jaringan irigasi Jitut dan Jides terdapat $74 \%$ kegiatan yang mempunyai debit $\geq 5$ liter/detik. semakin besar debit pada jaringan irigasi maka akan terjadi kelancaran aliran pada jaringan irigasi. Namun demikian terdapat beberapa faktor yang menyebabkan kelancaran aliran air pada jaringan irigasi yaitu dipengaruhi oleh cuaca yang mempengaruhi debit dan volume pada waduk (sumber air) jaringan irigasi serta kondisi jaringan yang lain pada daerah irigasi. Selain itu terdapat beberapa kegiatan yang terbangun tidak pada daerah irigasi tapi terbangun pada wilayah permukiman yang akhirnya tidak dimanfaatkan untuk pertanian namun untuk drainase permukiman seperti gambar 1 berikut.

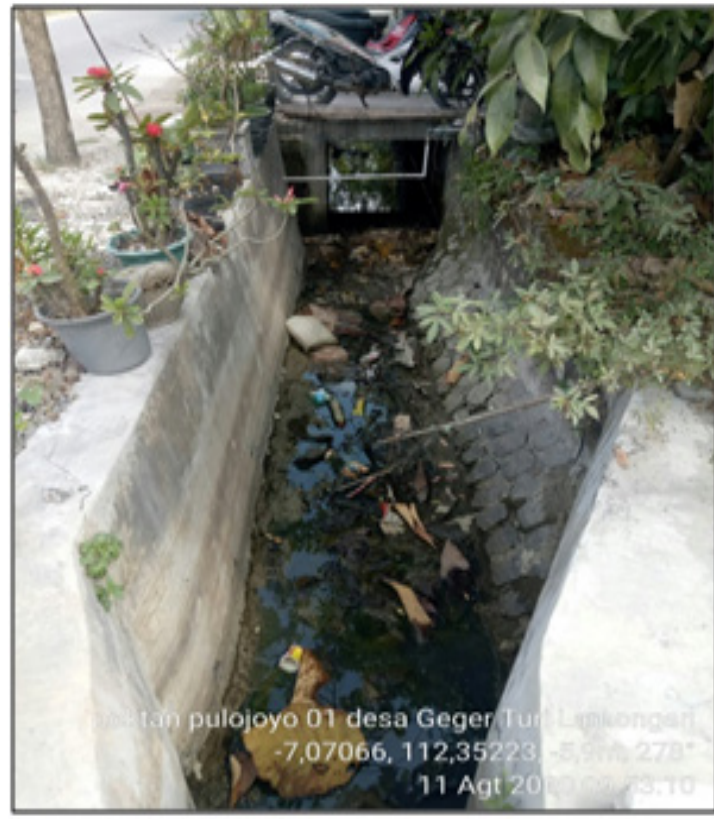

\section{Gambar 1}

\section{Jaringan Irigasi yang Terbangun pada Wilayah Permukiman}

Sedangkan efektivitas pada kegiatan pengadaan sarana prasarana teknologi tepat guna adalah mampu meningkatkan pendapatan petani terutama dengan pengelolaan alat mesin pertanian dalam bentuk unit pelayanan jasa alat mesin pertanian. Pada sub kegiatanhand traktorsebagian besar petani mengelola dengan UPJA sehingga dapat meningkatkan pendapatan, hal ini juga dilakukan pada sub kegiatan traktor roda empat namun traktor roda empat yang disalurkan hanya 3 unit dan disalurkan pada tahun 2018 untuk tahun berikutnya sistem pengelolaan traktor roda empat dengan sistem brigadealat mesin pertanian. Pada power thresher pompa air 4 dim dan 6 dim terdapat peningkatan jumlah alat mesin pertanian yang disalurkan lebih dari $2 \%$ namun pengelolaan tidak dalambentuk UPJA tetapi dalambentuk iuran oleh petani sehingga tidak meningkatkan pendapatan kelompok tani. Sedangkan pada transplanter (alat tanam) hanya disalurkan pada tahun 2019 dan tidak dimanfaatkan, hal ini disebabkan tidak 
adanya kecocokan dengan lahan pertanian di wilayah tersebut serta mendapat protes dari buruh tanam di wilayah kelompok tani yang mendapat bantuan. Sehingga sebagian besar kegiatan pengadaan sarana prasarana teknologi tidak guna tidak efektif dalam mencapai hasil yang diinginkan.

Faktor yang menyebabkan ketidak efektifan program pengembangan sarana prasarana pertanian lebih diakibatkan oleh kesalahan pada pendisposisian kegiatan dari Dinas ke kelompok tani atau pada proses pemilihan calon lokasi calon penerima (CPCL), seperti yang terjadi pada sub kegiatan dam parit, sumur panthek serta kegiatan pengadaaan sarana prasarana teknologi tepat guna. Selain itu keefektifan program juga dipengaruhi oleh jenis perencanaan. Kegiatan yang berasal dari aspirasi masyarakat melalui musrenbang cenderung lebih efektif dari pada kegiatan yang berasal penunjukkan langsung atau pendisposisian langsung dari dinas. Namun demikian karena sebagian besar kegiatan berhasil atau efektif maka kesimpulan dari program adalah efektif dalam mencapai hasil yang diinginkan.

\section{Keberlanjutan Program Pengembangan Sarana Prasarana Pertanian}

Keberlanjutan menurut Bappenas (2017) adalah kondisi program atau kegiatan setelah tidak mendapat intervensi dari pemerintah. Keberlanjutan juga untuk mengetahui penurunan kualitas output dari program pengembangan sarana prasarana pertanian. Berikut ini hasil penelitian keberlanjutan program pengembangan sarana prasarana pertanian seperti pada tabel 4.

Jika melihat perbandingan hasil analisis data pada tabel 3 dan 4 terjadi

Tabel 4. Hasil Penelitian Keberlajutan Program Pengembangan Sarana Prasarana Pertanian

\begin{tabular}{|c|c|c|c|c|c|}
\hline \multirow[t]{2}{*}{ Kegiatan } & \multirow[t]{2}{*}{ Sub kegiatan } & \multicolumn{4}{|c|}{ Keberlanjutan } \\
\hline & & $\begin{array}{c}\text { Kualitas } \\
\text { output }\end{array}$ & Kesimpulan & $\begin{array}{l}\text { Peran serta } \\
\text { Masyarakat }\end{array}$ & Kesimpulan \\
\hline \multirow{4}{*}{$\begin{array}{l}\text { Pengembangan } \\
\text { sumber-sumber air } \\
\text { untuk irigasi air } \\
\text { permukaan }\end{array}$} & $\begin{array}{l}\text { Pembangunan } \\
\text { embung }\end{array}$ & $44 \%$ & Tidak Berhasil & $62,5 \%$ & Berhasil \\
\hline & $\begin{array}{l}\text { Pembangunan dam } \\
\text { parit }\end{array}$ & $20 \%$ & Tidak berhasil & $47 \%$ & Tidak berhasil \\
\hline & $\begin{array}{l}\text { Pembangunan long } \\
\text { storage }\end{array}$ & $78 \%$ & Berhasil & $64 \%$ & Berhasil \\
\hline & $\begin{array}{l}\text { Pembangunan } \\
\text { sumur panthek }\end{array}$ & $0 \%$ & Tidak berhasil & $0 \%$ & Tidak berhasil \\
\hline $\begin{array}{l}\text { Pembangunan jalan } \\
\text { usaha tani }\end{array}$ & - & $64 \%$ & Berhasil & $32 \%$ & Tidak berhasil \\
\hline $\begin{array}{l}\text { Pembangunana dan } \\
\text { atau rehabilitasi Jitut } \\
\text { dan Jides }\end{array}$ & - & $67 \%$ & Berhasil & $20 \%$ & Tidak berhasil \\
\hline \multirow{6}{*}{$\begin{array}{l}\text { Pengadaan sarana } \\
\text { prasarana teknologi } \\
\text { tepat guna }\end{array}$} & Traktor roda empat & $0 \%$ & Tidak berhasil & $100 \%$ & Berhasil \\
\hline & Hand traktor & $-11 \%$ & Tidak berhasil & $77 \%$ & Berhasil \\
\hline & Power thresher & $0 \%$ & Tidak berhasil & $22 \%$ & Tidak berhasil \\
\hline & Pompa air $4 \mathrm{dim}$ & $0 \%$ & Tidak berhasil & $81 \%$ & Berhasil \\
\hline & Pompa air $6 \mathrm{dim}$ & $0 \%$ & Tidak berhasil & $83 \%$ & Berhasil \\
\hline & Transplanter & $0 \%$ & Tidak berhasil & $0 \%$ & Tidak berhasil \\
\hline
\end{tabular}

Sumber: Data Primer Diolah, 2020 
penurunan kualitas output. Penurunan kualitas output ini dipengaruhi oleh ada atau tidaknya pemeliharaan yang dilakukan pada kegiatan. Pada kegiatan pengembangan sumber-sumber air untuk irigasi air permukaan, kegiatan yang melakukan pemeliharaan dan pengelolaan hanya sekitar $60 \%$ hal ini mengakibatkan kegiatan mengalami penurunan volume menjadi kurang dari $500 \mathrm{~m}^{3}$ dan ketersediaan air mengalami penurunan. Sedangkan pada kegiatan pembangunan jalan usaha tani hanya terdapat $32 \%$ kegiatan yang melakukan pemeliharaan dan pengelolaan. Pengelolaan dan pemeliharaan pada jalan usaha tani dilakukan dengan pembatasan beban kendaraan selain itu juga dilakukan dengan memperbaiki sisi kanan dan kiri jalan yang mengalami longsor.

Sedangkan pada kegiatan pembangunan dan atau rehabilitasi jaringan irigasi Jitut dan Jides pemeliharaan dan pengelolaan dilakukan oleh Himpunan petani pemakai air (HIPPA). Namun kondisi di lapangan, karena pembangunan jaringan irigasi dilaksanakan dengan sistem kontraktual (pihak ketiga) maka sebagian besar jaringan mempunyai kualitas yang buruk dan mengakibatkan petani tidak melakukan pemeliharaan karena menganggap kerusakan berasal dari kesalahan pada waktu pembangunan sehingga hanya sedikit jaringan irigasi yang dilakukan pemeliharaan.

Sedangkan pada kegiatan pengadaan sarana prasarana teknologi tepat guna sebgaian besar mengaami penurunan kualitas output.Selain diakibatkan oleh tidak adanya pengelolaan dan pemeliharaan penurunan kualitas output juga diakibatkan oleh adanya modernisasi alat mesin pertanian, seperti pada power thresher yang sebagian besar masyarakatnya beralih ke penggunaan combine untuk panen padi sehingga power thresher tidak digunakan lagi.

\section{SIMPULAN}

Program pengembangan sarana prasarana pertanian mulai dilaksanakan pada tahun 2018.Sejak pelaksanaan program pengembangan sarana pertanian produksi padi di Kabupaten Lamongan mengalami penurunan. Sebelum pelaksanaan program produksi padi sebesar 924.933 ton pada tahun 2017 sedangkan pada tahun 2020 turun menjadi 839.742 ton (BPS Provinsi Jawa Timur, 2020). Salah satu penyebab hal ini adalah tidak efektif dan keberlanjutannya program pengembangan sarana prasarana pertanian sebagai salah satu program yang mendukung kebijakan peningkatan produksi padi.Program pengembangan sarana prasarana pertanian hanya efektif mencapai hasil yang diinginkan pada tahun awal pembangunan selanjutnya kualitas output program mengalami penurunan dan mengakibatkan keefektifan program juga menurun.

\section{UCAPAN TERIMA KASIH}

Penulis mengucapkan terima kasih kepada Badan Perencanaan dan Pembangunan Nasional (Bappenas) yang sudah memberikan beasiswa untuk melanjutkan studi di Magister Perencanaan Wilayah dan Kota Universitas Gajah Mada tahun 2019 - 2021 serta memberikan dana bantuan penelitian sehingga penelitian ini dapat terlaksana dengan baik.

\section{DAFTAR PUSTAKA}

Bappenas RI. (2017). Peraturan Menteri Perencanaan Pembangunan Nasional atau Kepala Badan Perencanaan Pembangunan Nasional Nomor 1 Tahun 2017 Tentang Pedoman Evaluasi Pembangunan Nasional. Jakarta.

BPS Kabupaten Lamongan. (2019). Data PDRB Kabupaten Lamongan 2019. Kabupaten Lamongan. 
BPS Kabupaten Lamongan. (2020a). Angka Kemiskinan 2019. Kabupaten Lamongan.

BPS Kabupaten Lamongan. (2020b). Data Produksi dan Produktivitas Padi. Kabupaten Lamongan.

BPS Kabupaten Lamongan. (2020c). Indeks Pembangunan Manusia. Kabupaten Lamongan.

BPS Provinsi Jawa Timur. (2020). Produksi Padi Provinsi Jawa Timur tahun 2015 - 2020. Surabaya: BPS Provinsi Jawa Timur.

Cresswell, J. W. (2017). Research Design : Pendekatan Kualitatif, Kuantitatif, dan Mixed (Edisi Ketiga). Yogyakarta: Pustaka Belajar.

Dethan, Yulianti., Bungananaen, Wilhelmus., \& Messah, Yunita A. (2015). Evaluasi Kinerja Embung Oeltua. Jurnal Teknik Sipil, Volume IV , 224-234.

Dunn, William N. (2003). Analisis Kebijakan Publik. Yogyakarta: Gajah Mada University Press.

Istighfaroh, Hikma Nur. (2016). Faktor - faktor yang mempengaruhi produksi padi di Kabupaten Lamongan. ITS SURABAYA: Skripsi Statistika.

Miraza, B. H. (2005). Perencanaan dan Pengembangan Wilayah. Bandung: ISEI.

Pramono, R. Widod. Dwi, \& Suminar, Ratna Eka. (2019). Ekonomi Wilayah untuk Perencanaan Tata Ruang. Yogyakarta: DEEPUBLISH.
Rahmaniar. (2018). Dampak Pembangunan Irigasi dalam Meningkatkan Kesejahteraan Petani. Rez Publica, 4(No. 2), 1-11.

Saragih, Rufdiantho. (2017). Perencanaan Wilayah dan Pengembangan Ekonomi Lokal Berbasis Pertanian. Yogyakarta: Pustaka Belajar.

Suminar, Ratna Eka. (2018). Dampak Pengembangan Jalan Usaha Tani (JUT) pada Kawasan Pertanian di Kabupaten Sleman Provinsi Daerah Istimewa Yogyakarta. Plano Madani, 81-88.

Tarigan, Robinson. (2007). Ekonomi Regional: Teori dan Aplikas. Jakarta: PT.Bumi Aksara.

Wibisana, Malana Ikram. (2017). Analisis Kebutuhan Pengairan Kawasan Pertanian Berdasarkan Bencana Kekeringan di Kabupaten Lamongan Berbasis Sistem Informasi Geografis. Institut Teknologi Sepuluh Nopember Surabaya: Skripsi PWK.

Winarno, Budi. (2014). Kebijakan Publik: Teori, Proses dan Studi Kasus. Yogyakarta: CAPS (Center of Academic Publishing Service). 